\title{
S)
}

ISSN 2278 - 0211 (Online)

\section{Distance Education as a Strategy towards Employee Skills Development: A Case Study of Kilimanjaro Region}

\author{
Dr. Amembah A Lamu Amos \\ Lecturer, Department of Marketing, Mwenge Catholic University, Tanzania
}

\begin{abstract}
:
Education is a vital element in the process of innovation and development of: organizations, governments and societies. The need for the employee to develop: skills, knowledge, experiences and competence necessitates that they become innovative towards learning. Distance education is a flexible strategy through which the employee could use to learn in order to meet the changing demands of the workplace. Research questions: what factors influence the uptake of distance education as an innovative learning strategy among employees? To what extent is distance education implemented to develop employees? What is the perception of employees towards distance education as an innovative strategy towards skills development? Research hypotheses: there is a significant difference in the mean perception of workers on the skills development of workers in distance education by gender. The study used a quantitative research approach and the design was correlational survey. The study covered two universities in Kilimanjaro. Data collection was done using: questionnaires and interview schedules. The findings were analysed through frequencies, percentages, means and T-test for the hypotheses. The study found out that: employees had equal opportunity to pursue their career development through distance education and distance education increases competency, improves employee skills and work experience. Also, most employees were involved in distance education however many employees did not receive support for their education from employers. Therefore, the study concluded that distance education has influence on employee development.
\end{abstract}

Keywords: Distance education, skills development, innovation, strategy, learning

\section{Introduction}

Consistent changes in the working environment require that organizations should be apt and quick to find innovative solutions to issues that take place in their environment. But this will only be possible if both the organization and their employees have the urgency to make changes. Organizational environments are dynamic therefore there is a need in organizations that requires employees to be up-to-date with new knowledge, skills, abilities, competency, policies, systems, and process in order to operate effectively at work. Also, the high demands in most careers require employees to meet their goals according to specific time periods. Most organizations demand that these goals should be achieved both quantitatively and qualitatively. Hence employees have recognized the need for being up to date, competent and effective at work. Therefore, the aspect of constant learning and development has made most of the employees to pursue their further studies in different fields of their specialization in order to upgrade themselves.

Open and distance learning is a field of education that focuses on teaching/learning methods and technology with the aim of fostering teaching and learning processes, often on an individual basis, to students who are not physically present in a traditional educational setting such as a classroom. It has been described as a process to create and provide free access to learning resources when the source of information and the learners are separated by time and distance, or both. The programme aims at bridging the time, geographical, economic, social and educational and communication distance between student and institution, student and academics, student and courseware and student and peers Among the more commonly used terms related to open and distance learning are the following: correspondence education, home study, independent study, external studies, continuing education, distance teaching, adult education, technology-based or mediated education, learner-centered education, open learning, open access, flexible learning, and distributed learning (MQA, 2011)

\subsection{Statement of the Problem}

Education is a vital element in the development of organizations, government institutions and the society in a country. The plan of the Tanzanian government is to educate its population in order to raise a generation that can be selfreliant in all aspects of life especially work. Similarly, organizations and the society also demand that their employees 
should be knowledgeable, competent and effective in an ever dynamic and competitive working environment. Studies that have been conducted show that there has been an increase in the uptake of flexible education programs from employees such as part-time evening programs, online learning as well as distance learning. But Kamal and Sultan 2002 (as cited in Ustati and Hassan 2013) found that graduates of Open Distance Learning (ODL) institutions in developing countries were considered second rate and less likely to attain jobs or engage in higher education; because many of these programs are not perceived as having social value, and their motivation to compete is low (Rashidetal 2015). Therefore, the paper aimed at investigating strategies that could be used in distance education in orders to develop the skills of the employees.

\subsection{Research Questions}

- What factors influence the uptake of distance education as an innovative learning strategy among employees?

- To what extent is distance education implemented to develop employees?

- What is the perception of employees towards distance education as an innovative strategy towards skills development?

\subsection{Research Hypotheses}

- H1 There is a significant difference in the mean perception of workers on the skills development of workers in distance education by gender

\subsection{Conceptual Framework}

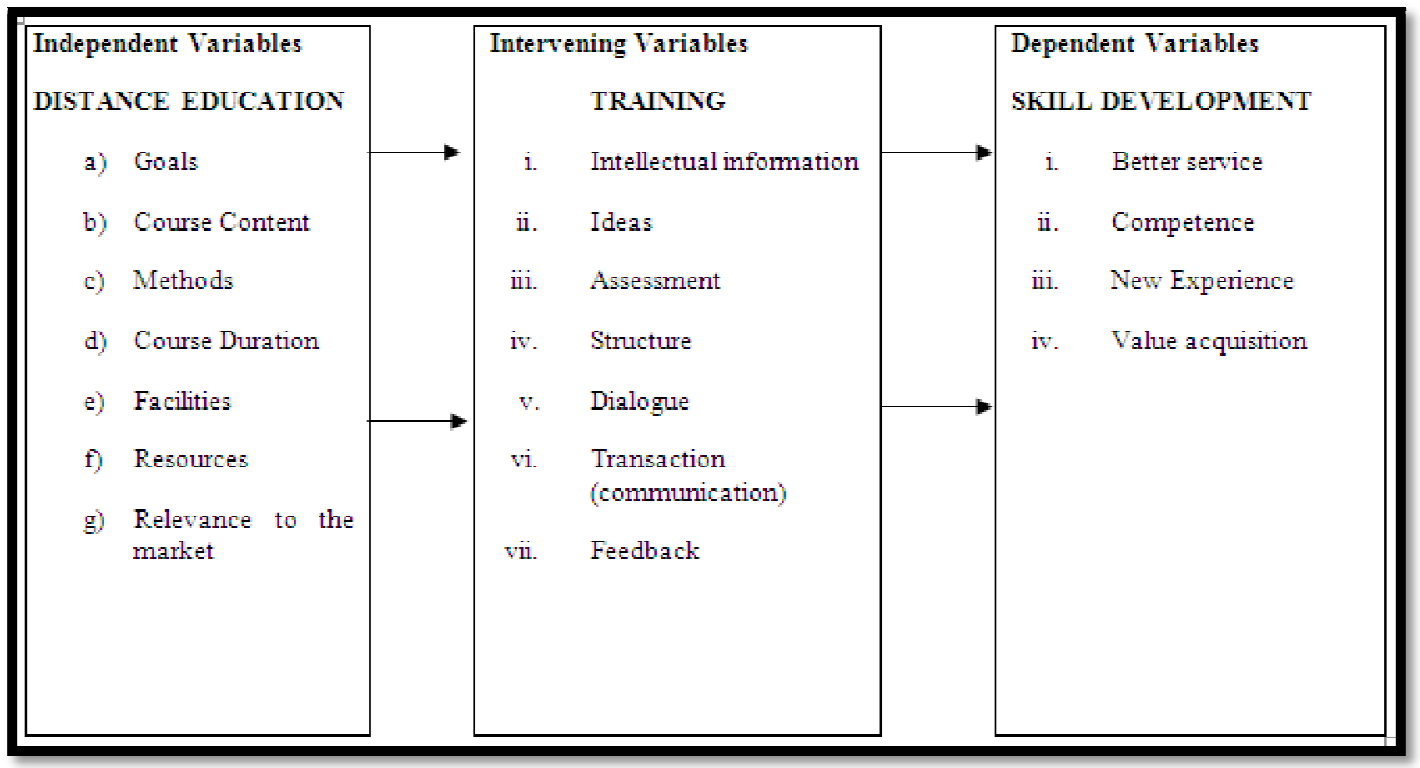

Figure 1: Conceptual Framework

Researcher's Own Construction, (2019)

The independent variables such as goals, course content, course duration, facilities and resources of the institutions will influence the career development of an employee through enabling variables such as Intellectual information, Ideas, Structure, Dialogue, Transaction and Feedback which will bring about a change in skills, knowledge, competence, communication, training and working environment of the employees. The influence of both the independent and intervene variables might cause a positive or negative effect on employee career development.

\section{Literature Review}

Distance education as mode of education has been in existence for many years especially in the developed countries as well as some few developing countries. Most develop countries have succeeded in implementing distance education as a medium for the advancement of education and training of their citizens. But lack of infrastructure and professional competence in open and distance learning remains important barriers. However, these forms of educational delivery have come to stay, and many countries are looking at open and distance learning as a major strategy for expanding access, raising quality and ensuring cost-effectiveness (MQA, 2011). The ever-changing environment in most organizations today requires employees who are more skillful, experienced and competent. This need has been the motivating factor for organizations and employees in their quest for better effectiveness and efficiency. Hence according to these studies distance education could be a solution to finding such quality because of its flexibility nature.

Wright, Dhanarajan \& Reju 2009 (as cited in Ustati \& Hassan 2013) observed that in developing nations, distance education tends to be perceived as a solution for the problem of increasing population with too few institutions to accommodate the growth. This study agreed with the fact that distance education could be a strategic avenue in the development of employees. As Ashcroft 2013, observed that in developed countries, distance education is often used to promote professional development and lifelong organizational learning. Raheena Raza \& Terry Allsop (2006) also argued that distance learning is now seen as a legitimate means through which organizations could use to develop employee 
skills. They explained that distance education has numerous advantages such as: wider access and cost efficiency. Secondly, rapid expansion in the past three decades suggests that there exists a ready-made infrastructure which can be capitalised upon to extend skills development. Also, more recent advancements in educational technologies suggest that ODL may be the solution for overcoming the gap between those who have had access to education and those who have not.

Therefore policy-makers in orgaisations should purpose to upgrade the skills of their workforce through ODL institutions who potentially have significant roles to play. As a means of delivering education, these institutions theoretically have a number of advantages, including cost efficiency and the ability to access students at the margins. Raheena Raza \& Terry Allsop (2006). This suggestion regards distance education as a key strategy towards the fulfillment of knowledge acquisition and dissemination. It also solidifies the purpose of the study that distance education could be used as mode and medium of employee career development.

In a case by (Adams 2009), "five research studies that were similar in design; each presented hiring managers with two hiring situations. In both hiring situations respondents were asked to choose between an applicant with college degree credits earned in a traditional, face-to-face program and a second applicant. The alternative applicants in these studies held degrees that qualified them for the job equally, but their coursework had been completed either half online (and half in a face-to-face setting) or completely online. The hiring managers, then, were asked to select one of two applicants in each situation. In the first situation, an average of $96 \%$ of gatekeepers preferred applicants with credits that were earned completely in residence as compared to those whose credits were earned completely online. In the second situation, an average of $70 \%$ preferred applicants with credits earned completely in residence as compared to those who had earned one half their credits online." This case scenarios shows that distance education is still not yet acceptable fully as an effective mode of education. However, this does not take away the fact that distance education does not develop knowledge, skills and competencies of the trainee, especially if the program is developed with student-based philosophy. Also, the nature distance education is that those who attend such programmes have a self-driven attitude ready to do more work on their own because they understand what they what. Hence the issue of knowledge, skills, experience and competency acquisition cannot be doubted.

In another study by, Kim Parker, Amanda Lenhart and Kathleen Moore (2011), public and college presidents differed over the educational value of online courses. Whereby only $29 \%$ of the public said that online courses offer an equal value compared with courses taken in a classroom. Half (51\%) of the college presidents surveyed said that online courses provide the same value. They also found out that Adults who had undertaken a course online had a somewhat more positive view of the value of this learning format: $39 \%$ said that a course taken online provides the same educational value as one taken in person, a view shared by only $27 \%$ of those who had not taken an online course. Among those who believed the most important role college plays is to prepare students for the working world, 59\% said that online classes provide the same educational value as in-person classes. Also, those presidents who said that the role of college is to promote personal and intellectual growth, only $43 \%$ said that online learning offers an equal value. Only $29 \%$ of all respondents said online classes offer an equal value. Six-in ten said online courses do not offer the same value as classes taken in person, and 11\% were unsure. These studies expose the differences in perception about distance education from employer's perspective. But they also show that distance education could be valuable if both the students and educational institutions do press for better value out of the programmes that they offer.

Demographically Kim Parker et al (2011) also found out that the issue of distance learning was fairly consistent across major demographic groups. In spite of the fact that they had grown up in a digital world, young adults are as skeptical about online learning as are their older counterparts. Among those younger than 30 , only $28 \%$ said that a course taken online is equal in value to a course taken in person; $67 \%$ said it is not. The same is true for those ages 30 and older: $30 \%$ said an online class offers the equivalent value of a class taken in person, 58\% say it does not. Further those who believe that the mission of higher education is to prepare students for the workforce are more likely to say that online courses provide equal value to a person classes (59\% vs. 40\%). Meanwhile, presidents who believe that the mission of higher education is to promote personal and intellectual growth are less enthusiastic about the value of online courses$43 \%$ say they are equal in value to in-person classes, while a $56 \%$ majority said they are not.

Most distance education programs are done by adult learners because, "Adult learners have a wide variety of reasons for pursuing learning at a distance: constraints of time, distance, and finances, the opportunity to take courses or hear outside speakers who would otherwise be unavailable, and the ability to come in contact with other students from different social, cultural, economic, and experiential backgrounds" (Willis, 1993).

\section{Research Methods}

The study used a quantitative research approach and the design was correlational survey. Also, the study covered two universities in Kilimanjaro. The sample of the study was 25 university lectures. Data collection was done using: questionnaires and interview schedules. The findings were analysed through frequencies, percentages, means and T-test for the hypotheses.

\section{Findings}

\subsection{Type of Institution}

The respondents were asked about the type of institution that they worked for (private or public). The following were there results were obtained: 


\begin{tabular}{|c|c|c|}
\hline Institution & Frequency & Percent \\
\hline Public & 13 & 52 \\
\hline Private & 12 & 48 \\
\hline Total & 25 & 100 \\
\hline \multicolumn{2}{|c|}{ Table 1: Type of Institution } \\
Source: Field Data (2018)
\end{tabular}

From the Table 2above the results shows that more employees from public universities had undertaken distance education 13 (52\%) while 12 (48\%) of the private universities had undertaken distance education. As much as the results have a small difference, they still imply that many private universities employees found it difficult to attend distance education as an option to career development

\subsection{Respondents' Gender}

From the question which sought to find out the gender of the respondents. The following data was obtained:

\begin{tabular}{|c|c|c|}
\hline Gender & Frequency & Percent \\
\hline Male & 20 & 80 \\
\hline Female & 5 & 20 \\
\hline Total & 25 & 100 \\
\hline \multicolumn{3}{|c|}{ Table 2: Gender Identity } \\
Source: field data, (2018)
\end{tabular}

The data from Table 3shows that the number of male respondents who had attended distance education was 20 $(80 \%)$ and for the female respondents was $(20 \%)$. This implies that more male had attended distance education to develop their careers in higher learning institutions

\subsection{Respondents Age}

In the question which sought to find out the age bracket of the employees. The following data was obtained from the respondents:

\begin{tabular}{|c|c|c|}
\hline Age & Frequency & Percent \\
\hline $22-34$ & 1 & 36 \\
\hline $35-44$ & 8 & 32 \\
\hline $45-54$ & 4 & 16 \\
\hline $55-64$ & 3 & 12 \\
\hline 65 and over & 1 & 4 \\
\hline Total & 25 & 100 \\
\hline
\end{tabular}

Table 3: Respondents Gender

Source: field data, (2017)

The data from Table 4above shows that more respondents in the age bracket between 22-34 9(36\%) had attended distance education followed by 35-44 8(32\%). While only one respondent was above. Three respondents were above the age bracket of 55-64 and 65 and above. This implies that younger employees had undertaken distance education as strategy for career development. It also implies that younger employees had the flexibility of undertaking distance education which by nature requires more time for self-study, non-traditional and technologically oriented. Another implication is that employees in the higher age bracket might have reached their retirement age and were no longer working or interested in furthering their studies. Demographically Kim Parker et al (2011) also found out that the issue of distance learning was fairly consistent across major demographic groups. In spite of the fact that they had grown up in a digital world, young adults are as skeptical about online learning as are their older counterparts. Among those younger than 30 , only $28 \%$ said that a course taken online is equal in value to a course taken in person; $67 \%$ said it is not. The same is true for those ages 30 and older: $30 \%$ said an online class offers the equivalent value of a class taken in person, $58 \%$ say it does not.

Most distance education programs are done by adult learners because, "Adult learners have a wide variety of reasons for pursuing learning at a distance: constraints of time, distance, and finances, the opportunity to take courses or hear outside speakers who would otherwise be unavailable, and the ability to come in contact with other students from different social, cultural, economic, and experiential backgrounds" (Willis, 1993). Willis's observation supports the argument that adult learners have different experiences and are able to reason differently. Therefore, they can easily formulate and adopt their own methods of learning in order to fulfill a certain learning goal. The goal also acts as a catalyst in the learning process because it motivates the learner to pursue his or her educational need. 45BVGFTR 


\subsection{Categories of Work}

From the question which sought to find out the categories of work from the respondents. The following data was obtained:

\begin{tabular}{|c|c|c|}
\hline Category of Work & Frequency & Percent \\
\hline Teaching & 16 & 64 \\
\hline Non-teaching & 7 & 28 \\
\hline Both teaching and non-teaching & 2 & 8 \\
\hline Total & 25 & 100 \\
\hline
\end{tabular}

Table 4: Category of Work

Source: Field Data, (2018)

The data in the 4.5 above shows that teaching staff were 16 (64) of the sample, non-teaching were 7 (28\%) while 2 $(8 \%)$ were both teaching and non-teaching. The results imply that more respondents were into teaching but it is also a reflection of the target population where the research was conducted. It also implies that because of the nature of distance education those in the teaching fraternity had better access, knowledge, ability and flexibility to undertake distance education.

\subsection{The Level of Distance Education that was undertaken}

From the question which sought to find out the level of distance education undertaken. The following demographic information was obtained.

\begin{tabular}{|c|c|c|}
\hline Level of Education & Frequency & Percentage \\
\hline Certificate & 10 & 40 \\
\hline Diploma & 1 & 4 \\
\hline Bachelor & 4 & 16 \\
\hline Postgraduate & 5 & 4 \\
\hline Masters & 1 & 16 \\
\hline PhD & 4 & 100 \\
\hline Total & 25 & \\
\hline
\end{tabular}

Table 5: The Level of Distance Education Undertaken

Source: Field Data, (2018)

The data in Table 6shows that more respondents had undertaken distance education at the level of certificate $10(40 \%)$, while the other categories had less employees who had undertaken distance education. These figures might imply that because many respondents were employed, they found it had to attend distance education at higher levels. It might also imply that the nature (mode, content, time and teaching methods) of distance education could have made them not to pursue distance education at higher levels. Finally, these figures might also imply that most employees who attended distance education had already attained education at the highest level. Therefore, they pursued distance education at a lower level because developing their careers. As depicted in Table 7whereby 25 (100\%) of the respondents agreed that they attended distance education in an area that had relevancy within their profession.

\subsection{Relevancy in the Area of Employment (Career)}

From the question which sought to find out whether the course that was pursue had any relevancy in the respondent's area of employment (career). The following data was obtained:

\begin{tabular}{|c|c|c|}
\hline Relevancy in the Area of Employment & Frequency & Percentage \\
\hline Yes & 25 & 100 \\
\hline Total & 25 & 100 \\
\hline
\end{tabular}

Table 6: Relevancy in the Area of Employment (Career)

Source: Field Data, (2018)

The results in the table above 4.8 show that 25 (100\%) of the respondents agreed that the distance education course that they pursued was relevant to their profession. This implies that distance education could be used to develop employees' career. It also implies that employees in both public and private institutions had the same purpose, goal and need when pursuing distance education (relation in their profession).

\subsection{The mode of Distance Education}

From the question which sought to find out the mode of distance education attended. The following data was obtained. 


\begin{tabular}{|c|c|c|}
\hline Mode of Education Attended & Frequency & Percent \\
\hline Partly class and self study & 9 & 36 \\
\hline Full self study through text books & 8 & 32 \\
\hline Online learning & 8 & 32 \\
\hline Total & 25 & 100 \\
\hline
\end{tabular}

Table 7: The Mode of Distance Education

Source: Field Data, (2018)

The figures in the table above 4.7 above shows that 9 (36) respondents had undertaken a distance education program through a partly class and self study, $8(32 \%)$ full self study through text books and $8(32 \%)$ through online learning. The figures imply that most respondent pursued distance education through partly class and self study because that was the mode that was offered by the institution. On the other hand, other modes had equal percentages from the respondents.

\subsection{Extent of Satisfaction}

From the question which sought to find out the level of satisfaction among the respondents in regards to the program. The following data was obtained:

\begin{tabular}{|c|c|c|}
\hline Satisfaction with Program & Frequency & Percent \\
\hline Very satisfied & 2 & 8 \\
\hline Satisfied & 3 & 12 \\
\hline Neutral & 10 & 40 \\
\hline Dissatisfied & 10 & 40 \\
\hline Total & 25 & 100 \\
\hline
\end{tabular}

Table 8: Extent of Satisfaction

Source: Field Data, (2018)

\subsection{Distance Education Factors}

From the question which sought to find out the factors that would influence the uptake of distance education. The following data was obtained: SA Strongly Agree 5, Agree 4, Undecided 3, Disagree 2, SD Strongly Disagree 1.

\begin{tabular}{|c|c|c|c|c|c|c|c|c|c|c|c|}
\hline $\begin{array}{l}\text { Distance Education } \\
\text { Factors }\end{array}$ & SA 5 & $\%$ & A 4 & $\%$ & U 3 & $\%$ & D 2 & $\%$ & SD 1 & $\%$ & Mean \\
\hline 1. Skills development & 19 & 76 & 5 & 20 & 1 & 4 & - & - & - & - & 4.72 \\
\hline 2. Employment & 7 & 28 & 11 & 44 & 4 & 16 & 2 & 8 & 1 & 4 & 3.84 \\
\hline 3. Promotion & 6 & 24 & 9 & 36 & 3 & 12 & 4 & 16 & 3 & 12 & 3.44 \\
\hline 4. Career goal & 11 & 44 & 8 & 32 & 3 & 12 & - & - & 3 & 12 & 3.96 \\
\hline 5. $\quad$ Colleagues & 3 & 12 & 7 & 28 & 2 & 8 & 6 & 24 & 7 & 28 & 2.72 \\
\hline 6. $\quad$ Course content & 8 & 32 & 11 & 44 & 1 & 4 & 1 & 4 & 4 & 16 & 3.72 \\
\hline 7. Method of instruction & 9 & 36 & 10 & 40 & 2 & 8 & 1 & 4 & 3 & 12 & 3.84 \\
\hline 8. Assessment & 6 & 24 & 10 & 40 & 3 & 12 & 3 & 12 & 3 & 12 & 3.52 \\
\hline 9. Course duration & 6 & 24 & 10 & 40 & 4 & 16 & 1 & 4 & 4 & 16 & 3.68 \\
\hline 10. Facilities & 7 & 28 & 10 & 14 & 4 & 16 & 1 & 4 & 3 & 12 & 3.76 \\
\hline 11. Resources & 9 & 36 & 9 & 36 & 2 & 8 & 2 & 8 & 3 & 12 & 3.8 \\
\hline 12. Resource market & 7 & 28 & 10 & 40 & 6 & 24 & - & - & 2 & 8 & 2.92 \\
\hline 13. My boss & 4 & 16 & 7 & 28 & 3 & 12 & 5 & 20 & 6 & 24 & 2.92 \\
\hline 14. Government regulations & 3 & 12 & 7 & 28 & 2 & 8 & 5 & 20 & 8 & 32 & 2.68 \\
\hline 15. Market needs & 9 & 36 & 10 & 40 & 3 & 12 & - & - & 3 & 12 & 3.88 \\
\hline 16. Self-gratification & 10 & 40 & 9 & 36 & 2 & 8 & 1 & 4 & 3 & 12 & 3.88 \\
\hline $\begin{array}{l}\text { 17. Flexibility of the } \\
\text { program }\end{array}$ & 12 & 48 & 9 & 36 & 2 & 8 & 1 & 4 & 1 & 4 & 4.25 \\
\hline 18. Less costly & 7 & 28 & 9 & 36 & 2 & 8 & 1 & 4 & 6 & 24 & 34 \\
\hline
\end{tabular}

The data in the Table 9shows that, most respondents agreed that they would pursue distance education studies to develop their skills 19 (13.3\%) strongly agreed and 5 (3.1\%). A mean perception of 4.72 was also obtained which implies that most respondents agreed that distance education has an influence on the development of employee skills

Employment, 7(28\%) strongly agreed while 11 (44) agreed that pursuing their education through distance education would influence their opportunity for employment. However, 4 (16) undecided and 2 (8\%) disagreed that distance education influenced employment. A mean perception of 3.84 was also obtained which implies that distance has an influence on career development. 
Promotion, most respondents agreed that promotion was an important factor why they would undertake distance education which was as follows: 6 (24\%) strongly agreed, 9 (36\%) agreed with a mean perception of 3.44; Course content: strongly agreed $8(32 \%), 11(44 \%)$ and mean perception of 3.72. Method of instruction: strongly agreed 9 (36\%), $10(40 \%)$ agreed and a mean perception of 3.84 was obtained: Career: $11(44 \%)$ strongly agreed and $8(32 \%)$ agreed and a mean perception of 3.96 was obtained: Assessment: strongly agreed 6 (24\%), agreed 10 (40\%) with a mean perception of 3.52 was obtained: Course duration: strongly agreed $6(24 \%)$, agreed $10(40 \%)$ with a mean perception of 3.52 was obtained: Facilities: strongly agreed 7 (28\%), agreed 10 (40\%) and a mean perception of 3.69 was obtained: Resources: strongly agree 9 (36\%), agreed 10 (36\%) with a mean perception of 3.69 was obtained: Resource market: strongly agreed $7(28 \%), 10(40 \%)$ and mean perception of 3.80 was obtained: Market needs: strongly agreed $9(36 \%), 10(40 \%)$ agreed and a mean perception of 3.88 was obtained: Boss: 3 (12\%) strongly agree, 7 (28\%) agree, 5 (20\%) disagree and 2 (24\%) strongly disagreed and a mean perception of 2.92 was obtained : Self-gratification: strongly agreed 10 (40\%), agreed 9 (36\%) with a mean perception of 3.88 was obtained Flexibility: strongly agreed 12 (48\%), agreed 9(36\%) with a mean perception of 4.25: Less cost: strongly agreed 7 (28\%), agreed 9 (36\%) and a mean perception of 3.69 was obtained

The highest mean that was obtained was at 4.25 represented flexibility of the program. This implies that employees would like to pursue distance education because it's flexible and it could allow them to purse their education in order to develop their career. Factors like my boss and government scored less because these factors did not play an important role in the decision making of employee's choice to pursue distance education programs. One human resource said that, "employees are free to choose an area that they would like to pursue distance education." "Employees pursue distance education to add competency in their area of specialization".

\subsection{Implementation of Distance Education}

On the question which sought to find out the influence of distance education and its implementation. The following data was obtained: Indicate the extent to which you agree or disagree that distance education is implemented in your institution

\begin{tabular}{|c|c|c|c|c|c|c|c|c|c|c|c|}
\hline Implementation of Distance Education & SA & $\mathbf{\%}$ & $\mathbf{A}$ & $\mathbf{\%}$ & $\mathbf{U}$ & $\mathbf{\%}$ & $\mathbf{D}$ & $\mathbf{\%}$ & $\mathbf{S D}$ & $\mathbf{\%}$ & Mean \\
\hline $\begin{array}{c}\text { Employees regularly upgrade their skills } \\
\text { through distance education }\end{array}$ & 4 & 16 & 5 & 20 & 6 & 24 & 4 & 16 & 6 & 24 & 2.88 \\
\hline $\begin{array}{c}\text { I have knowledge that my institution } \\
\text { supports distance education }\end{array}$ & 4 & 16 & 9 & 36 & 5 & 20 & 6 & 24 & 1 & 4 & 3.38 \\
\hline $\begin{array}{c}\text { Employees who attend training are given } \\
\text { flexible working hours }\end{array}$ & 2 & 8 & 7 & 28 & 4 & 16 & 6 & 24 & 6 & 24 & 2.72 \\
\hline $\begin{array}{c}\text { Employees are given opportunity to attend } \\
\text { distance education }\end{array}$ & 7 & 28 & 9 & 36 & 4 & 16 & 3 & 12 & 2 & 8 & 3.64 \\
\hline $\begin{array}{c}\text { Employees are given resources to pursue } \\
\text { their training }\end{array}$ & 1 & 4 & 5 & 20 & 2 & 8 & 8 & 32 & 9 & 36 & 2.24 \\
\hline $\begin{array}{c}\text { Both male and female employees have } \\
\text { equal opportunity to pursue distance } \\
\text { education }\end{array}$ & 10 & 40 & 4 & 16 & 6 & 24 & 2 & 8 & 3 & 12 & 3.64 \\
\hline $\begin{array}{c}\text { Our employees are involved in distance } \\
\text { education }\end{array}$ & 4 & 16 & 8 & 32 & 7 & 28 & 2 & 8 & 4 & 16 & 3.24 \\
\hline $\begin{array}{c}\text { I have knowledge that my institution offers } \\
\text { distance education }\end{array}$ & 11 & 44 & 2 & 8 & 5 & 20 & 2 & 8 & 5 & 20 & 3.48 \\
\hline $\begin{array}{c}\text { There is distance education for our } \\
\text { employees }\end{array}$ & 5 & 20 & 6 & 24 & 7 & 28 & 3 & 12 & 4 & 16 & 3.20 \\
\hline $\begin{array}{c}\text { I have received support for my distance } \\
\text { education through my institution }\end{array}$ & 2 & 8 & 9 & 36 & 2 & 8 & 2 & 8 & 10 & 40 & 2.64 \\
\hline
\end{tabular}

Table 10: Implementation of Distance Education Source: field data, (2018)

SA-Strongly Agree -5, A-Agree -4, U- undecided -3, D- Disagree -2, SD Strongly Disagree -1

According to data shown in table, not many respondents upgraded their skills through distance education in institutions as shown in the table $4(16 \%)$ were undecided, $5(20 \%)$ disagreed and 6 (24\%) strongly disagreed while a mean perception of 2.88 was also obtained. Also, as much as many employees had knowledge that their institutions offered distance education 4(16\%) strongly agreed and 9 (36\%) agreed while still other did not know that their institutions offered distance education 5 (20\%) undecided, and 6 (24\%) disagreed. This implies that distance education hasn't been fully utilized to promote employee development.

Employees who attended distance education also disagreed that they had flexible working hours to support their career development through distance education undecided 4 (16\%), disagreed $6(24 \%)$ and 6 (24\%) strongly disagreed which is also shown with a mean perception of 2.72 . That implies that employers gave their employees opportunity to pursue their career development through distance education but not many gave them flexible working hours.

In regards to permission to attend distance education most employees agreed that they were given opportunity to continue their education through distance education, strongly agreed 7 (28\%), agree 9 (36\%) with a mean perception of 3.64 Employees also disagreed that they were given resources to pursue their distance education 8 (32\%) disagreed and 9 
(36\%) strongly disagreed. This implies that as much as employees are given opportunity to study, it was up to them to find out resources that could assist them to develop their careers.

In the same finding the respondents agreed that both male and female were given equal opportunity to develop their careers through distance education. 10 (40\%) strongly agreed and $4(16 \%)$ agreed with a mean perception of 3.64 . this implies that there was no discrimination in regards to career development and each employee had equal opportunity to study through distance education. One human resource manager said that, "every employee has freedom to develop their career through distance education." "Employees are also free to put in individual efforts towards career development." Another one said that the situation about distance education in her institution was good and that distance helps to increase the competency of the employees."

The findings in table also show that not many employees in higher learning institutions were involved in distance education. 7 (28\%) undecided, 2 (8\%) disagree and 4 (16\%) strongly disagree with mean perception of 3.24 . Although 12 employees agreed that employees are involved in distance education 4 (16\%) strongly agreed and 8 (32\%) agreed. This implies that distance education has not been fully explored as a mode of career development.

The findings in the table also show that there was $\mathrm{n}$ fair balance between employees who felt that they had knowledge that there institution offered distance education: 11 (44\%) strongly agreed, 2 (8\%) agreed, 5 (20\%) undecided, $2(8 \%)$ disagreed and 5 (20\%) strongly disagreed that is 13 and 12 respondents respectively.

The findings from the human resource managers also agree that the institutions support those who pursue their career through distance education. In the following ways: employees are given time to study, support professional development, increase their knowledge for performing better at work.

\subsection{Competence and Development of Employees}

\begin{tabular}{|c|c|c|c|c|c|c|c|c|c|c|c|c|}
\hline \multicolumn{2}{|c|}{$\begin{array}{l}\text { Competence and Skills Development } \\
\text { Factors }\end{array}$} & SA & $\%$ & A & $\%$ & $\mathbf{U}$ & $\%$ & D & $\%$ & SD & $\%$ & mean \\
\hline 1. & $\begin{array}{l}\text { I am more competent because of } \\
\text { distance education }\end{array}$ & 10 & 40 & 15 & 60 & - & - & - & - & - & - & 4.40 \\
\hline 2. & $\begin{array}{l}\text { Distance education has improved my } \\
\text { skills }\end{array}$ & 9 & 36 & 13 & 52 & 3 & 12 & - & - & - & - & 4.24 \\
\hline 3. & $\begin{array}{l}\text { Distance education has improved my } \\
\text { experience }\end{array}$ & 8 & 32 & 40 & 56 & 3 & 12 & - & - & - & - & 4.20 \\
\hline 4. & $\begin{array}{l}\text { The distance education program that } \\
\text { I attended was skills oriented }\end{array}$ & 9 & 38 & 13 & 52 & 3 & 12 & - & - & - & - & 4.24 \\
\hline 5. & $\begin{array}{l}\text { The distance program that I attended } \\
\text { was competency based }\end{array}$ & 8 & 32 & 14 & 56 & 3 & 12 & - & - & - & - & 4.20 \\
\hline 6. & $\begin{array}{l}\text { I am more effective at work because } \\
\text { of distance education }\end{array}$ & 7 & 28 & 14 & 56 & 3 & 12 & - & - & 1 & 4 & 4.04 \\
\hline 7. & $\begin{array}{l}\text { I am a better employee because of } \\
\text { distance education }\end{array}$ & 4 & 16 & 12 & 48 & 5 & 20 & 3 & 12 & 1 & 4 & 3.60 \\
\hline 8. & $\begin{array}{l}\text { I am motivated to work because of } \\
\text { distance education }\end{array}$ & 3 & 12 & 15 & 60 & 3 & 12 & 2 & 8 & 2 & 8 & 3.60 \\
\hline 9. & $\begin{array}{l}\text { I am a better communicator because } \\
\text { of distance education }\end{array}$ & 3 & 12 & 16 & 64 & 3 & 12 & 2 & 8 & 1 & 4 & 3.72 \\
\hline 10. & $\begin{array}{l}\text { I feel more comfortable at work } \\
\text { because of distance education }\end{array}$ & 4 & 16 & 16 & 64 & 2 & 8 & 1 & 4 & 2 & 8 & 3.76 \\
\hline 11. & $\begin{array}{l}\text { I am easy to work with because } \\
\text { distance education }\end{array}$ & 4 & 16 & 14 & 56 & 3 & 12 & 2 & 8 & 2 & 8 & 3.64 \\
\hline 12. & $\begin{array}{l}\text { I am a team player because of } \\
\text { distance education }\end{array}$ & 6 & 24 & 14 & 56 & 1 & 4 & 2 & 8 & 2 & 8 & 3.80 \\
\hline
\end{tabular}

Table 11: Influence of Distance Education on Competence and Skills

Development of the Employees Source: Field Data, (2018)

SA-Strongly Agree -5, A-Agree -4, U-Undecided -3, D-Disagree -2, SD Strongly Disagree -1

In a question which sought to find out the results between distance education and competence the following results were found: many respondents agreed that distance education had an influence in the acquisition of competence. 9 (36\%) strongly agreed while 13 (52\%) agreed to the statement that their competence was result of distance education. This implies that those who attended distance education were able to utilize the knowledge, skills and experiences that they acquired to develop their career through being competent. A mean perception of 4.16 was found to ascertain this argument.

In a question which sought to find out the results between distance education and skills development; the following results were found: The findings in the table above shows that many respondents agreed that distance education contributed to the development of employee skills. $10(40 \%)$ strongly agreed while $15(60 \%)$ agreed to the statement that distance education developed their skills. This implies that those who attended distance education were advantage to develop their skills hence advance their career. This can also be seen in the table where most respondents said that they 
pursued distance education in their area of specialization. A mean perception of 4.40 was found to ascertain this argument. One human manager agreed that there employees had benefit from distance education because they were able to write report well, write proposals from the field, conduct seminars and improvement in public speaking The following studies agree to this argument that distance education improves skills: Wright, Dhanarajan and Reju 2009 (as cited in Ustati and Hassan 2013) observed that in developing nations, distance education tends to be perceived as a solution for the problem of increasing population with too few institutions to accommodate the growth. This study agrees with the fact that distance education could be a strategic avenue in the development of employees. As Ashcroft 2013, observed that in developed countries, distance education is often used to promote professional development and lifelong organizational learning. Raheena Raza and Terry Allsop (2006) also argued that distance learning is now seen as a legitimate means through which organizations could use to develop employee skills. They explained that distance education has numerous advantages such as: wider access and cost efficiency, secondly, its rapid expansion in the past three decades suggests that there exists a ready-made infrastructure which can be capitalised upon to extend skills development. Also, more recent advancements in educational technologies suggest that ODL may be the solution for overcoming the gap between those who have had access to education and those who have not.

In a question which sought to find out the results between distance education and employee experience the following results were found: The findings in the table above show that many employees agreed that distance education contributed to their good experience at their workplace. 15 (60\%) strongly agreed while 10 (40\%) agreed that distance education had a positive influence on their work experience. This implies that distance education could be used to develop employee experience and career development. A mean perception of 4.40 was found to ascertain this argument.

In a question which sought to find out the results between distance education and program skills orientation, the following results were found: The findings in the table...above show that many employees agreed that the distance education that they had attended was skills oriented. 9 (26\%) strongly agreed while 13 (52\%). While 3(12\%) were undecided on whether the distance education that they had attended was skills oriented. This implies that most institutions offered programmes that customized to the students needs but also employees selected to pursue courses that were skills oriented. This also means that employee could develop their careers positively after pursuing a program that was developed according to the market needs. A mean perception of 4.24 was found to ascertain this argument.

In a question which sought to find out the results between distance education and competence the following results were found: The findings in the table...show that most respondents agreed that the distance education that they attended was competency based. This implies that distance education has a positive influence on the competency of the employees. Hence career development. A mean perception of 4.20 was found to ascertain this argument.

In a question which sought to find out the results between distance education and work effectiveness the following results were found: The findings in the table...show that most respondents agreed that distance education had contributed to their effectiveness at their workplace. 7 (28\%) strongly agreed and 14 (56\%) agreed that they were effective at work. This therefore implies that distance education does have a positive influence on the career development of employees. Harris et al. (2010) developed a list of characteristics that principals most often prefer in teacher applicants. They found that principals ranked strong communication skills, enthusiasm, and classroom management skills highest. Distance education has improved the skills, competence and performance of the employee. One human resource manager said.

Mason and Schroeder (2010) noted that professional characteristics such as proper certification, letters of reference, and transcripts are important and that principals use interviews to gauge personal attributes. Principals, then, tend to deem interviews, references, evaluations, and letters of recommendation as more effective means of learning about their applicants than coursework or strong academic credentials (Rutledge et al., 2008). A mean perception of 4.04 was found to ascertain this argument.

In a question which sought to find out the results between distance education and being a better employee, the following results were found: The findings in the table above show that that as much many respondents felt that distance education had made them better employees 4 (16\%) strongly agreed and 12 (48\%) agreed; while others few respondents still felt that distance education did not contribute towards their betterment as employees 5 (20\%) undecided, 3 (12\%) disagreed and $1(4 \%)$ strongly disagreed. This implies that there was still opportunity to make distance education more effective and acceptable a medium of career development. A mean perception of 3.60 was found to ascertain this argument. Kim Parker, Amanda Lenhart and Kathleen Moore (2011), public and college presidents differed over the educational value of online courses. Whereby only $29 \%$ of the public said that online courses offer an equal value compared with courses taken in a classroom. Half (51\%) of the college presidents surveyed said that online courses provide the same value. They also found out that Adults who had undertaken a course online had a somewhat more positive view of the value of this learning format: $39 \%$ said that a course taken online provides the same educational value as one taken in person, a view shared by only $27 \%$ of those who had not taken an online course. Among those who believed the most important role college plays is to prepare students for the working world, $59 \%$ said that online classes provide the same educational value as in-person classes. Also, those presidents who said that the role of college is to promote personal and intellectual growth, only 43\% said that online learning offers an equal value. Only $29 \%$ of all respondents said online classes offer an equal value. Six-in ten said online courses do not offer the same value as classes taken in person, and 11\% were unsure. These studies expose the differences in perception about distance education from employer's perspective. But they also show that distance education could be valuable if both the students and educational institutions do press for better value out of the programmes that they offer.

In a question which sought to find out the results between distance education and motivation to work the following results were found: The findings on the table show that most respondents agreed that distance education had strong influence on their motivation at work. $3(12 \%)$ strongly agreed and $15(60 \%)$ agreed that they were motivated 
because of distance education. This implies that distance education motivated employees because they were able to gain skills, knowledge and experiences that act as vital elements in the process of career development. A mean perception of 3.60 was obtained to ascertain this argument.

In a question which sought to find out the results between distance education and being a better communicator, the following results were found: The findings in the table reveal that those who attended distance education positively agreed that it had made them better communicators, $3(12 \%)$ and 16 (64\%). This implies that those who attended distance education had an opportunity to develop their communication because they gained knowledge and skills that gave them confidence to communicate However some respondents felt that distance education did not influence their communication at work $3(12 \%)$ undecided $2(8 \%)$ disagreed and 1(4\%) strongly disagreed. This implies that though distance education had a positive influence on communication there were still more opportunities to make it better in order to produce well rounded students. A mean perception of 3.72 was found to ascertain this argument.

In a question which sought to find out the results between distance education and comfortability at work, the following results were found: The findings in table shows that most respondents agreed that distance education had made them comfortable to work, 4 (16\%) strongly agreed while 16 (64\%) agreed that distance education had made them comfortable. This implies that distance education could make employees comfortable at their workplace possibly because employees were able to acquire the necessary skills, knowledge and experiences that enabled them to become more comfortable at work. A mean perception of 3.76 was found to ascertain this argument.

In a question which sought to find out the results between distance education and the ease to work with, the following results were found: The findings in the table show that most respondents agreed that distance education had made them easy to work with. 4 (16\%) strongly agreed and 14 (56\%) agreed that distance education had made them easy to work with. This implies that distance education could be used as a medium for developing one's career because employees who attended these programmes were better skilled, competent and experienced. Hence, they were easy to work with. A mean perception of 3.64 was found to ascertain this argument.

In a question which sought to find out the results between distance education and being a team player, the following results were found: The findings in the table show that many respondents agreed that distance education had made them better team players at their workplace, 6 (24\%) strongly agreed while 14 (56\%)agreed. This implies that those who attended distance education acquired knowledge and skills that made them better employees and better team players. This would in the long run contribute to the development of their career. A mean perception of 3.72 was found to ascertain this argument.

\subsection{Hypotheses Testing}

\subsubsection{Assumptions}

- The population from which the samples were obtained is normally or approximately normally distributed

- The samples are independent of one another

- The variances of population are equal

- $\quad$ The subjects are randomly and independently sampled

\subsubsection{Decision Rules}

- If the observed significance level (P-value) $<0,005$ significance level, reject hypotheses

- If the observed significance level (P-Value) $\geq 0.05$ significance level, do not reject the hypotheses

\begin{tabular}{|c|c|c|c|c|c|c|c|c|c|}
\hline & \multicolumn{2}{|c|}{$\begin{array}{c}\text { Test for Equality of } \\
\text { Variances }\end{array}$} & \multicolumn{2}{|c|}{$\begin{array}{c}\text { T-test for Equality of } \\
\text { Means }\end{array}$} & & & \\
\hline Variables & $\mathbf{F}$ & Sig. & T & df & $\begin{array}{c}\text { Sig. (2- } \\
\text { tailed) }\end{array}$ & $\begin{array}{c}\text { Mean } \\
\text { Difference }\end{array}$ & Standard & Lower & Upper \\
\hline Importance & .445 & .511 & -1.043 & 23 & .308 & -.39722 & .38086 & -1.18509 & .39064 \\
\hline $\begin{array}{c}\text { Skills } \\
\text { development }\end{array}$ & 2.496 & .128 & -.581 & 23 & .567 & -.19167 & .33003 & -.87439 & .49106 \\
\hline
\end{tabular}

Table 12

Source: Field Data, (2018)

A T-test was used to test whether employees' gender has significant relationship with the importance of distance education and implementation of distance education. The data in the table 4.16 shows that there was a significant value in the mean perception of importance and distance education. The P-value was .511. (Significant) the data also shows that there was no significant value between importance and skills development. The P-value was .128 (significant). However, a higher number of respondents agreed that distance education was important and they also agreed that it improved the skills of the employee. 


\begin{tabular}{|c|c|c|c|c|c|c|c|c|c|}
\hline & & \multicolumn{5}{|c|}{ Paired Differences } & \multirow{4}{*}{$\mathbf{t}$} & \multirow{3}{*}{$\mathbf{N}$} & \multirow{3}{*}{$\begin{array}{l}\text { Sig. (2- } \\
\text { tailed) }\end{array}$} \\
\hline & & \multirow[t]{3}{*}{ Mean } & \multirow[t]{2}{*}{$\begin{array}{c}\text { Std. } \\
\text { Deviation }\end{array}$} & \multirow[t]{2}{*}{$\begin{array}{l}\text { Std. Error } \\
\text { Mean }\end{array}$} & \multicolumn{2}{|c|}{$\begin{array}{l}95 \% \text { CI of the } \\
\text { Difference }\end{array}$} & & & \\
\hline & & & & & Lower & Upper & & & \\
\hline & & & &. & - & & & & \\
\hline $\begin{array}{c}\text { Hypotheses } \\
3\end{array}$ & $\begin{array}{c}\text { Implementation } \\
\text { Skills } \\
\text { development }\end{array}$ & -.85933 & 1.08032 & .21606 & -1.30527 & -.41340 & -3.977 & 24 & .001 \\
\hline
\end{tabular}

Table 13

Source: Field Data, (2018)

T-test was used to determine whether the implementation had a significant relationship with skills development. The data in the table above also shows that there was a significant relation between implementation and skills development. The P-value was .001. Therefore, the hypothesis was rejected.

\section{A summary of the findings}

The demographic data was balanced because most respondents were in the age bracket of 22 to 54 . Most respondents felt neutral about their satisfaction with distance education and both male and female employees had equal opportunity to pursue their career development through distance education. The study also found out that most employees were involved in distance education learning. However not many employees received support for their education from their employers, despite having equal opportunity to pursue their career development through distance education. Additionally, most respondents agreed that distance education improves the employee's: competency, skill, experience, makes them better, comfortable at work and better communicators

\section{Conclusions}

The study concluded that that there is a need for: organizations, institutions and governments to reform education policies so that employees as well other citizens can be able to develop their professions with knowledge, skills and competence through innovative distance education. The private sector has a major role in establishing working systems that will promote the adoption of innovative career development of their employees because most employees said that their organizations did not fully support their career development; most employees knew the importance of distance education. They were also interested in pursuing a course through distance education in order to develop their careers.

\section{Recommendations}

Employees could use the knowledge, skills and experiences that they obtained to pursue and develop their careers through distance education. They could also develop their career through distance learning if they choose a proper programme that is relevant and rich in their area of specialization. Employees should take opportunity and pursue various courses through distance education to develop their careers. Employees should also be active in seeking for ways in which they can improve their careers innovatively. Organizations should give equal opportunity to every employee to develop their career. The government should reform education policies so that employees of organizations as well other citizens can be able to develop their professions with knowledge, skills and competence through distance education. The government could also establish more learning centers to promote distance education. Lastly, pursuing distance education does not guarantee employment but it does increase the competency, skills, knowledge and experience that could play a very important role in the development of one's careers.

\section{References}

i. Adams, J. (2009). The acceptability of online bachelor's degrees as criteria for admission to medical school programs. The Oschner Journal, 9(1), 4-10.

ii. $\quad$ Alexander, S. (1998). A touch of virtual class. Computerworld, 32, 77-78, 82-83.

iii. Alison Mead Richardson (2009). Crossing the Chasm- Introducing Flexible Learning into the Bostwana Technical Education Program: From Policy to Action. International Review in research in Open Distance Learning. Vol 10 number 4

iv. Ary, D Jacobs, C.L., Sorensen, C \& Razavieh, A (2010). Introduction to Research in Education. CA: Wadsworth.

v. Brooke Bennett (2014). Attitude Plus Aptitude Will Determine Altitude Motivating our students in an online environment.

vi. Butcher, N. (2009). Open Educational Resources and Higher Education. South Africa: SAIDE publishers

vii. Chute, A. G, Thompson, M. M \& Hancock, B. W. (1999). The McGraw-Hill handbook of Distance Learning. New York: McGraw-Hill.

viii. Cosmas B. F. Mnyanyi and Tolly S. A. Mbwette (2003). Open and distance learning in Developing Countries: the past, the Present and the Future. Open University of Tanzania, Tanzania

ix. Cupertino CA, J.H Sandholz, C, Ringstaff, \& D, C Dwyer (1992). Classroom Management: Teaching in high-tech Environments: First-fourth year Apple Classroom of Tomorrow, Advanced Technology Group, Apple Computer, Inc.

$x$. Hillary Perraton, H. (1998). A theory for distance education 
xi. Gallagher, P. A \& McCormick, K. (1999). Student Satisfaction with two-way Interactive Distance Learning for Delivery of early Childhood Special Education Coursework. Journal of Special Education Technology, 14, 32-47.

xii. Jennifer R.D. Burgessa and Joyce E.A. Russell (2003). The Effectiveness of Distance Learning Initiatives in Organizations. Journal of Vocational Behavior. Academic Press

xiii. J.R.D. Burgess, J.E.A. Russell The effectiveness of distance learning initiatives in organizations Journal of Vocational Behavior 63 (2003) 289-303 291

xiv. Kim Parker, Amanda Lenhart and Kathleen Moore (2011). The Digital Revolution and Higher Education College Presidents, Public Differ on Value of Online Learning. Pew research centre.

xv. Malaysian Qualifications Agency, (MQA), (2011). Guidelines to Good Practices: Open and Distance Learning. Malaysia: Higher Education office Publishers. International Journal of African and Asian studies. www.iiste.org ISSN 2409-6938. Journal Vol.7, 201524

xvi. Maruff Akinwale OLADEJO \& Abiodun M GESINDE (2014). Trends and Future Directions in Open and Distance Learning Practice in Africa. Journal of Education and Practice. www.iiste.org ISSN 2222-1735 (Paper) ISSN $2222-$ 288X (Online) Vol.5, No.18, 2014

xvii. M. Knowles (1990).The Adult Learner, $4^{\text {th }}$ ed. Houston, TX: Gulf publishing.

xviii. McNabb, J (1994). Telecourse Effectiveness: Findings in the Current Literature. Tech Trends, Pg 39-40

xix. Mwilongo Kardo, J (2014). Reaching all through Open and Distance Learning in Tanzania.

xx. Mzumbe University.

xxi. Ogula, P.A (2009). A Handbook on Educational Research. (2 ${ }^{\text {nd }}$ ed) Nairobi: New Kemit.

xxii. Phillips, J., Phillips, P.P. \& Zuniga, L. (2000). Evaluating the Effectiveness and the Return on investment of elearning. American Society for Training and Development. http:// www.astd.org/virtual_community/research/What_Works/e-learning//2/2/2017.

xxiii. Prime learning, Inc (2001).http://www.primelearning.com5/2/2017.

xxiv. Porter David (1994). New directions in distance learning: interim report. B.C Canada

xxv. Ponzurick, T. G. France, K. R., \& Logar, C. M. (2000). Delivering Graduate Marketing Education: An Analysis of faceto-face Versus Distance Education. Journal of Marketing Education, 22, 180-187.

xxvi. $\quad$ Raheena Raza and Terry Allsop (2006). Using Distance Education For Skills Development. International Research Foundation for Open Learning (IRFOL) Cambridge Knowledge and research Department of international development.

xxvii. Rashid Aderinoye, Richard Siaciwena \& Clayton R. Wright (2009). Regional Focus Issue Editorial: A Snapshot of Distance Education in Africa. International Review of Research in Open Distance Learning. Volume 10 Number 4.

xxviii. Raymond A. Noe (1999). Employee Training \&Development. MacGraw-Hill

xxix. $\quad$ Schamber L (1998). Distance systems for distance education. Eric Document Reproduction service No. ED 304111.

xxx. Sherry L \& Morse R.A (1995). An Assessment of Training Needs in the use of Distance Education for Instruction. International Journal of Communications, 1 (1), 5-22.

xxxi. Vander Ven K (1994). Viewpoint: The Power and Paradox of Distance Education. The Chronicle of Distance Education and Communication. Online Journal 7 Usenet Newsgroup alt education.

xxxii. Ustati, R., and S. Hassan ( 2013). Distance learning students' need: Evaluating interactions from Moore's theory of transactional distance. Turkish Online Journal of Distance Education 14 (2):292-304.

xxxiii. Willis B. (1992). Instructional Development for Distance Education. ERIC Document Reproduction Service No. ED 351007

xxxiv. Willis B (1993). Strategies for Teaching at a Distance. ERIC Document Reproduction Service No. ED 351008

xxxv. Wolfe L. (1994). The digital co-op: Trends in the virtual Community. The University of British Columbia Continuing Studies.

xxxvi. When do employees accept e-learning? (2001). Retrieved June 18, 2002 from http://www.astd.org/virtual community/research/. 